\title{
Risk Management for Private Clients
}

\section{WILL HUMAN CAPITAL BE ANOTHER CASUALTY OF TECHNOLOGICAL DISRUPTION?}

\section{By Ed McCarthy}

Editor's Note: In 2017, our practitioner-led global practice analysis process led to enhanced coverage of risk management in the CFA Program curriculum. This is part of an ongoing series of articles examining risk management and other curriculum topics that reflect practical knowledge and skills needed in today's investment industry.

CFA Institute members historically have focused primarily on institutional investment management, but advising on private wealth management is gaining ground. Bob Dannhauser, CFA, head of global private wealth management at CFA Institute,

Clients must understand the need to integrate their human-capital profiles with their investment-asset allocations.

The disruptive effect of new technologies on life insurance may alter risk management outcomes.

It remains to be seen whether robo-advisers will play a role in curbing such self-destructive investment behaviors as complacency and panic. reports that up to a third of North American CFA Institute members are involved in some aspect of individual asset management.

The advisory processes for institutional and private wealth often overlap but can differ significantly in areas such as risk management. CFA Institute recently released its Level III Refresher Reading, Risk Management for Individuals, which reviews the learning outcomes that CFA candidates should master in this area.

\section{VALUING HUMAN CAPITAL}

An ability to earn an income-the foundation of human capital-is a major asset that is often neglected by advisers, says Dannhauser: "We are particularly interested in having practitioners account for the entirety of an individual's balance sheet, including human capital, and that's what a lot of risk management overlooks."

Human capital is defined as the risk-adjusted present value of an investor's long-term expected labor income. The valuation model presented in the reading discounts future income by a nominal risk-free rate and a factor for occupational income volatility, as shown in the following formula:

$$
\begin{aligned}
& H C_{0}=\sum_{t=1}^{N} \frac{p\left(s_{t}\right) w_{t-1}\left(1+g_{t}\right)}{\left(1+r_{f}+y\right)^{t}}, \text { where } \\
& H C_{0}=\text { value of human capital } \\
& p\left(s_{t}\right)=\text { probability of surviving to year (or age) } t \\
& w_{t}=\text { income from employment in period } t \\
& g_{t}=\text { annual wage-growth rate }
\end{aligned}
$$

$$
\begin{aligned}
& r_{f}=\text { nominal risk-free rate } \\
& y=\text { occupational income volatility } \\
& N=\text { length of working life in years }
\end{aligned}
$$

A household's income stream can have equity-like volatility or more stable, bond-like characteristics. A start-upbusiness owner or securities trader, for example, would be more likely to experience income swings year to year, which a higher discount rate for occupational volatility would capture. In contrast, a household in which both spouses are tenured college professors or government employees with secure jobs will have less volatile, more bond-like incomes.

Human capital decreases as remaining working life shortens. Ideally, during the course of a career, excess cash flow from earnings is converted to financial capital, which eventually replaces depleted human capital to meet retirementincome needs. Approaching private wealth in this manner can help clients understand the need to integrate their human-capital profiles with their investment-asset allocations. Imagine a bond trader whose personal portfolio consists solely of volatile equities and whose $401(\mathrm{k})$ plan has a sizable position in her employer's stock. Both her income and investments are tied to the financial markets' health, so a 2008-2009 market scenario could cause both reduced earnings (or even unemployment) and portfolio losses. The college professors, however, can benefit from owning equity positions and other non-guaranteed assets to diversify their low-volatility human capital.

Tom Trainor, CFA, managing director with Hanover Private Client Corporation in Toronto, Canada, says his firm incorporates the concept of human-capital analysis, but he has two criticisms of the discounted-present-value approach. First, the formula requires too many estimates. Second, it produces a balance-sheet value, which he believes provides less useful information than an income-statement approach. Trainor values human capital by examining the client's aftertax net income over his working life. The income analysis then considers 1) employment risk in an economic downturn, 2) income volatility, 3) pension entitlement, and 4) morbidity and mortality projections. These factors influence the resulting investment portfolio design and recommendations for insurance products.

\section{EARNINGS RISK}

The employment risk and income volatility that Trainor considers reflect the same earnings risk that the formula addresses with its $y$ variable. Estimating an appropriate value for this discount factor could take on additional importance in coming years as technological disruptions affect a wider 
range of industries and occupations. A 2013 report from the Oxford Martin School titled "The Future of Employment: How Susceptible are Jobs to Computerization?" estimates that "about $47 \%$ of total US employment is at risk" from computerization. A March 2017 study by PwC put the percentage of US jobs at high risk of automation by the early 2030 s at $38 \%$. Other academics and business leaders also are raising the topic: Stephen Hawking, Bill Gates, and Elon Musk have all discussed automation's potentially harmful effect on different employment categories.

It's true that private-wealth clients are more likely to be in the position of owning or managing those businesses that hire at-risk workers, but that doesn't mean they will be immune to the effects of computerization. For example, will a trucking-company owner have sufficient capital to acquire driverless vehicles as quickly as UPS and FedEx? Can smallto mid-sized manufacturers afford to replace humans with robots-and the support systems they require-in order to remain competitive? The rise of artificial intelligence and smart automation could result in more widespread levels of earnings risk than currently assumed. These trends highlight the need for clients' continued investment in their employment-related skills and knowledge, plus advisers' need to review this topic with clients.

\section{RISK MANAGEMENT WITH INSURANCE PRODUCTS}

Disability and premature death can significantly reduce or eliminate human capital. Insurance products, such as disability-income insurance and life insurance, allow individuals to mitigate the financial effects of these events. Although designs of insurance products typically change slowly, several interesting trends have been emerging.

DETERMINING BIOLOGICAL AGE WITH DNA TESTING. DNA testing might allow for more precise life insurance underwriting through more accurate mortality estimates. Minneapolis, Minnesota-based GWG Life, which operates in the life insurance secondary market, recently started a project to use epigenetic prediction technology, a form of DNA testing, to forecast life expectancies. The technology's application is still being debated, but if it proves accurate, insurers likely will consider using it.

MONITORING HEALTH HABITS. According to the 2016 Insurance Barometer Study conducted by industry researchers LIMRA and Life Happens, more than $30 \%$ of total respondents and $51 \%$ of millennials would consider wearing an activity tracker and sharing those results with a life insurance company in return for financial rewards based on healthy habits. The John Hancock Vitality Program is an example of an insurer working to capture health data like that recorded by fitness monitors and using the data to encourage and reward healthy behaviors.

POLICY DESIGN. There have been some recent developments worth noting from around the world. Combination policies that provide both life insurance and some form of long-term care or critical-illness coverage are gaining acceptance. According to LIMRA, sales of these policies increased 37\% from 2014 to 2015. Global insurers are also innovating.
Johannesburg, South Africa-based insurer BrightRock offers a policy that combines disability-income coverage with coverage for additional expenses and a death benefit. The policy's provisions allow the insured to customize their coverage components as their needs change.

PRODUCT DISCLOSURE. Advances in technology have influenced insurers' underwriting processes, says Brian Fechtel, CFA, with Breadwinners' Insurance in Purchase, New York. Some insurers are underwriting based on socioeconomic factors such as an applicant's job or income without obtaining medical records or blood samples. In Fechtel's view, however, those advances in technology are not meaningful changes with respect to the life insurance product. As an example, he cites the lack of product transparency as an unresolved problem: "A technology improvement that needs to come along is the ability to access another insurer's policy illustrations online. ... It is difficult to obtain information about competitive products [and] the consumer is at a disadvantage," he points out in an email comment. Consumers share his sentiment. A recent LIMRA study found that "consumers want the ability to compare companies and products. Transparency is the new normal and helps take the mystery out of life insurance."

\section{ROBOS AS RISK MANAGERS}

Robo-advisers have a small slice of the investment management business: Moody's Investors Service reports that as of year-end 2016 and early 2017, Vanguard Personal Advisor Services ( $\$ 52$ billion of assets under management [AUM]), Schwab Intelligent Portfolios ( $\$ 12.3$ billion AUM), and Betterment ( $\$ 7$ billion AUM) were the largest services. The robos' AUM are projected to grow rapidly, however. Business Insider forecasts global robo AUM will reach $\$ 8.7$ trillion in 2020, up from an estimated $\$ 600$ billion in 2017, with annual year-over-year growth rates above $100 \%$ for the period.

The robos' investment management models and technologies continue to evolve. A 2016 report by Dominik Moulliet and Julian Stolzenbach with Deloitte Consulting in Frankfurt, Germany, grouped global robos into four evolutionary stages. The early services are ranked as level 1.0, with the leading-edge providers at level 4.0. About $80 \%$ of German, EU, UK, and US robos have level 3.0 capabilities, which the authors define as including algorithm-based adjustments and rebalancing proposals plus predefined investment rule sets. Level 4.0 providers are developing "fully automated investments, self-learning algorithms, and automatic asset shifts" with the ability to "shift between different asset classes based on changing market conditions and individual investment needs."

\section{TOO COMFY FOR COMFORT?}

Sources cite two potential behavioral risks for robo-clients, although all investors share these risks to some degree. The first is complacency: Returns have been good in recent years and the robos' algorithms appear to be working properly, so investors may stop paying attention to their portfolios. 
It could happen, agrees Ben Carlson, CFA, director of Institutional Asset Management with Ritholtz Wealth Management in Grand Rapids, Michigan. Ritholtz offers a roboservice aimed at younger investors, but Carlson cautions that investors who use the service still need to understand what's happening with their funds. "When you're with a robo-adviser and you're not going to have someone there to hold your hand and communicate on a regular basis, I think it's up to you to stay educated with what's going on in the markets and in your own portfolio and what could potentially be the range of outcomes," he says.

Jon Stein, CFA, CEO and founder of Betterment in New York City, rejects the idea that robo-advisers somehow make investors more complacent. Regardless of how investors access the market, understanding the risk involved and taking on the proper level of portfolio risk is essential, he says. Once the portfolio is established, he says, Betterment's automated tools keep investors "on track with guardrails that are established in our applications, with clear advice as they go with information and think about making changes."

\section{THE BEAR NECESSITIES}

Stein points out that "it's OK to be complacent with the right portfolio for you." He's right, and following that advice by sticking with inexpensive, globally diversified, long-only portfolios would help many investors avoid the subpar returns they earn by trying to time the markets. But Moulliet and Stolzenbach raise an important point about the robos' lack of long-term experience and how well the services will perform during a significant market pullback: "There are no mid- or long-term investment results yet for those solutions [that] combine ETFs into a synthetic product mix tailor-made to the client's risk appetite. ... Even if some market participants have been praising themselves for superior investment performance in the past (e.g., during a political shake-up), it remains to be proved that the robo is indeed the better adviser in the long run."

So, when the next inevitable bear market arrives, will robo-clients stick with their portfolios? "Or will they do what humans have always done when faced with a typical 25\%-50\% loss: cut and run?" asks Rodrigo Gordillo, managing partner with ReSolve Asset Management in Toronto, Canada, which offers an automated investing service.

Robo-providers recognize this scenario and are planning their communication strategies accordingly to keep investors on track for the long term, says Gordillo. These plans include "regular emails about how investments are risky in the short term but ultimately rewarding in the long term," he says. "They also post videos, hold webinars, and provide interactive tools aimed at helping investors build confidence in their approach during good times so they can stay on course during the bad times."
Additional strategies include emails timed to address investors' concerns at different stages of market decline, Gordillo maintains: "Send email number one when they are down 5\%; email two at $-10 \%$ percent; email eight at $-40 \%$, etc. No doubt the most thoughtful robo-advisers are already developing these campaigns right now in consultation with the world's foremost experts on investor behavior."

Email campaigns might work and replicate an adviser's role in helping investors stay the course, says Gordillo, but they might not. "Maybe there's no amount of email-automated empathy that can convince a frightened, instinctual animal to hold tightly to investment principles that fail so spectacularly every five to seven years," he says.

A certain element of the investing public will panic regardless of their investment method, says Carlson, but self-directed investors who transitioned to robos might benefit in stressful markets. "I think that maybe adding that one extra layer of protection between themselves and doing something irrational could actually help people," he says.

In addition to educational campaigns, some robos are using other methods to keep clients on track. One is to combine the robos' automated features with a human adviser in a hybrid model (or as one source called it, the "cyborg model"). A December 2006 survey of roughly 1,000 Schwab clients found that most respondents preferred a hybrid approach to an either-or model, and Betterment, Schwab, and Vanguard are all using or implementing this approach.

An alternative solution that some robos have adopted is to structure portfolios with the goal of avoiding the volatility levels that lead to investor panic. Gordillo's firm is taking that approach by offering globally diversified, quantitatively managed portfolios with target volatility levels. El Segundo, California-based Cambria Investments is also using portfolio design in its Cambria Digital Advisor automated platform to prevent self-destructive investment behaviors. According to Meb Faber, chief investment officer and co-founder, the firm's six model portfolios diversify globally with a tilt away from market cap to value. The unique feature in the firm's automated portfolios, however, is the use of futures and trend following. "Our default portfolio actually has a $50 \%$ allocation to trend-following strategies, and [with] those, historically, the goal has been to of course diversify, lower the volatility, but also to lower the drawdown of the portfolio," says Faber. "And so it's going to look a lot different, for better or for worse, but the goal is that it will make the client experience a little more palatable when times are bad."

Ed McCarthy is a freelance financial writer in Pascoag, Rhode Island.

\section{KEEP GOING}

CFA Program Refresher Reading Risk Management for Individuals: http://cfa.is/2njoZyH 